\title{
A DEFESA DO CONTRIBUINTE E 0 PROCESSO ADMINISTRATIVO FISCAL
}

\section{THE CONTRIBUTOR'S DEFENSE AND THE FISCAL ADMINISTRATIVE PROCESS

\begin{abstract}
ADMINISTRATIVE PROCESS
\end{abstract}

DEFENSE AND THE FISCAL

RVD

Recebido em

12.02.2021

Aprovado em.

23.03. 2021

\author{
Tainá Belo Paz da Silva ${ }^{12}$ \\ Suyene Monteiro da Rocha ${ }^{3}$
}

\section{RESUMO}

O presente trabalho teve como objetivo estudar o funcionamento do processo administrativo fiscal, sob a ótica do decreto lei no 70.235/72, com ênfase na sua fase contenciosa e concatenou com a execução dos meios de defesa do contribuinte deliberadamente apoiados nos princípios da constituição. A partir de seu objeto central de estudo o Processo Administrativo Fiscal (PAF) a pesquisa se caracteriza como descritiva, alicerçada no método dedutivo, com uma abordagem qualitativa, utilizando as técnicas documental e bibliográfica. Se caracteriza por ser um estudo multifacetado ao conectar o direito tributário, direito administrativo e o direito constitucional. Por fim a exposição desse trabalho teve como escopo a análise do funcionamento do PAF e concluiu-se sobre a importância do cumprimento das fases procedimentais de arguição de defesa do sujeito passivo no processo administrativo fiscal, com observância das garantias fundamentais constitucionais no âmbito administrativo, e evidenciou-se a importância das impugnações ante as atividades e arbitrariedades estatais.

PALAVRAS-CHAVE: contribuinte; defesa; processo administrativo fiscal.

\begin{abstract}
The present work had as objective to study the functioning of the fiscal administrative process, under the perspective of the decree law $n^{0} 70.235 / 72$, with emphasis in its litigation phase and concatenated with the execution of the taxpayer defense means

\footnotetext{
${ }^{1}$ Pós-Graduada em Direito e Processo Administrativo da Universidade Federal do Tocantins, Campus Palmas E-mail: taina belo@hotmail.com ORCID: https://orcid.org/0000-0001-5646-6561

${ }^{2}$ Quadra 108 Sul Alameda 06 Número 53, CEP:77020106, Palmas/TO.

3Doutora em Biodiversidade e Biotecnologia - BIONORTE/UFAM. Mestre em Ciências do Ambiente UFT. Professora Adjunta no curso de Direito da Universidade Federal do Tocantins. Coordenadora do grupo de pesquisa CNPq: Políticas Públicas Ambientais e Sustentabilidade. E-mail: suyenerocha@uft.edu.br. ORCID: https://orcid.org/0000-0001-6818-2013
} 
deliberately supported by the constitution principles. From its central object of study, the Fiscal Administrative Process (PAF), the research is characterized as descriptive, based on the deductive method, with a qualitative approach, using documentary and bibliographic techniques. It is characterized by being a multifaceted study by connecting tax law, administrative law and constitutional law. Finally, the exposition of this work had as its scope the analysis of the functioning of the PAF and it was concluded on the importance of complying with the procedural stages of the defense of the taxpayer in the tax administrative process, with observance of the fundamental constitutional guarantees in the administrative sphere, and the importance of challenges to state activities and arbitrariness was highlighted.

KEYWORDS: taxpayer; defense; tax administrative process.

\section{INTRODUÇÃO}

O Processo Administrativo Fiscal (PAF) federal brasileiro requer a compreensão do modelo previsto pelo seu Decreto regulamentador de ํㅜ 70.235/72. A observância da legislação envolve a abordagem das fases do processo, instâncias de julgamento compostas no primeiro, segundo e terceiro grau administrativo.

Entre os temas abordados nesse estudo serão de destaque a composição dos órgãos julgadores de cada instância, os recursos cabíveis, e associando diretamente a execução dos meios de defesa do contribuinte através da recorribilidade administrativa fundamentadas nos princípios constitucionais.

O PAF divide-se em fase não contenciosa e fase contenciosa, alvo esse último de enfoque neste artigo. Quanto às partes que compõem o processo são elas: o sujeito ativo, representado pelo Fisco (Fazenda Pública) e o sujeito passivo, que é o contribuinte.

O estudo inicia-se abordando o Processo Administrativo Tributário, com seus conceitos doutrinários, como ocorre a instauração da ação fiscal, fase não contenciosa do processo e uma explicação breve sobre fato gerador e obrigação tributária. $\mathrm{Na}$ segunda parte adentrou-se aos princípios constitucionais que regulam a defesa do contribuinte no processo. 
$\mathrm{Na}$ terceira parte e final chega-se ao contencioso do Processo Administrativo Fiscal, seus ritos, regras, prazos processuais, recursos competentes a cada instância administrativa, com ênfase na execução da ampla defesa pelo contribuinte. Pretendeuse nesse estudo expor todas as formas de recorribilidade administrativa do contribuinte relacionando arbitrariedades da Fazenda Pública, como também seus privilégios.

O presente trabalho teve o objetivo de explanar acerca de como ocorrem os tramites processuais do Processo Administrativo Fiscal Federal ou Processo Administrativo Tributário, as suas fases, os meios e as de defesa do contribuinte através das possibilidades de recursos nas instancias administrativas, tendo como norteadora a Constituição Federal do Brasil de 1988 e seus princípios, visto que nesta é garantido aos litigantes no processo administrativo o contraditório, ampla defesa, devido processo legal dentre outros.

\section{PROCESSO ADMINISTRATIVO TRIBUTÁRIO FEDERAL}

Processo Tributário é gênero, e as suas espécies são o processo administrativo fiscal (PAF) e o processo judicial tributário. O objeto de estudo deste trabalho é a parte administrativa do processo, o PAF, e dele serão tratadas as suas subespécies, chamadas de fase não contenciosa, que também é denominada de voluntária e a fase contenciosa ou bilateral.

Para um bom entendimento acerca dos sujeitos envolvidos e o porquê das suas ações durante o processo, se explica primeiramente sofre fato gerador e obrigação tributária.

Obrigação pode ser definida como uma relação de natureza pessoal e de caráter transitório, que deixa de existir quando ocorre o seu cumprimento. A partir desse mero conceito de obrigação, traça-se o entendimento de obrigação tributária, a seguir:

Carneiro (2019, p. 498) preceitua: 
Podemos dizer que a obrigação tributária é o vínculo através do qual o Estado (sujeito ativo da obrigação tributária) pode exigir do particular (sujeito passivo) uma prestação tributária (principal ou acessória).

No mesmo entendimento se tem codificado no Código Tributário Nacional no artigo 119 que: "sujeito ativo da obrigação tributária é a pessoa jurídica de direito público titular da competência para exigir seu cumprimento." E quanto ao sujeito passivo, regulamentado pelo art.121 define: "o sujeito passivo da obrigação principal é a pessoa obrigada ao pagamento de tributo ou penalidade pecuniária."

O sujeito passivo ao praticar um ato previsto em lei, faz surgir o fato gerador, e assim recebe o auto de infração pelo Fisco cobrando o pagamento do crédito tributário, e dessa forma nasce a obrigação de pagar tributo (obrigação tributária).

Para que se possa adentrar ao rito procedimental do administrativo tributário, é preciso primeiro entender como se inicia, como se forma, e de onde advém o seu tramite. A relação entre Fisco, representado pela Fazenda Pública, e o contribuinte se inicia primordialmente quando ocorre uma obrigação tributária entre essas duas partes, obrigação essa que nasce com a ocorrência de um fato gerador.

Cláudio Carneiro disserta em pormenores que o fator gerador tem a origem em uma situação hipotética prevista pelo legislador, que a transforma em lei, e que uma vez ocorrida, ela deixa de ser abstrata e passa ser concreta, enquadrando-se na tipicidade tributária, e gerando para quem a praticou o dever de pagar tributos.

Fato gerador é regulamentado pelo Código Tributário Nacional, o qual define a ocorrência do mesmo a partir da prática de um fato imponível pelo sujeito passivo de uma hipótese prevista em lei, gerando dessa forma uma obrigação de pagar tributo (obrigação tributária).

O processo administrativo fiscal é composto pelo contribuinte, que também pode ser chamado de sujeito passivo e pelo Fisco, que é a Administração Tributária. Ambos com seus direitos, um de cobrar e o outro de impugnar, se defendendo da exigência fiscal da qual não está de acordo.

Após a explicação do conceito de fato gerador e obrigação tributária, adentra-se ao Processo Administrativo Tributário, também denominado de PAF, que tanto é um 
instrumento normativo utilizado como forma de solução de conflitos na instância administrativa entre contribuinte e o agente o administrativo, de forma mais célere e menos dispendiosa como também é uma forma de controle de atos administrativos, especificamente de natureza fiscal, e principalmente quanto a exorbitantes benefícios fazendários.

Regulamentado pelo Decreto de nำ 70.235/72, tem seu conceito no âmbito do artigo 1ำ na sua íntegra: "Este Decreto rege o processo administrativo de determinação e exigência dos créditos tributários da União e o de consulta sobre a aplicação da legislação tributária federal".

Fala-se de legislação em âmbito federal, pois este referido decreto foi recepcionado pela Constituição em 1988, e adquiriu força de lei, só podendo assim ser alterado por lei posterior. Notou-se também pelo artigo, que o PAF serve tanto de consulta interpretativa como de exigência de créditos pelos entes federais.

Carneiro (2019, p. 58) assevera que:

O processo administrativo fiscal, como espécie do processo administrativo, também tem por objetivo 0 controle dos atos administrativos, com o fim de estabelecer um marco na aplicação do princípio da legalidade administrativa, passando, inclusive, se for o caso, por uma correção, sempre que se vislumbrar qualquer ameaça às liberdades e aos direitos dos contribuintes, como, por exemplo, a revisão do lançamento.

O PAF atua conforme os princípios da legalidade e controle dos atos, perdurando sempre durante 0 processo a possibilidade de correção de possíveis erros administrativos, como o equívoco em um lançamento tributário, e assegura de forma clara a defesa do contribuinte contra decisões, retrata a possibilidade de recorribilidade nas instancias e esferas administrativas como também na esfera judicial, enfatizando o uso do contraditório e da ampla defesa. No mesmo sentido Sabbag (2016, p.729 e 730):

O Poder Executivo, principalmente em relação à matéria tributária, detém em sua organização determinadas estruturas julgadoras, 
possibilitando o contraditório ao contribuinte insatisfeito. Trata-se de estruturas que se assemelham às do Poder Judiciário, com a presença de instâncias de julgamento - singulares (seções de julgamento) e colegiadas (câmaras, conselhos e tribunais) -, permitindo o fluxo do usualmente intitulado "processo administrativo tributário". A propósito, a última decisão administrativa é detentora do timbre de irrecorribilidade na órbita da Administração, não fazendo coisa julgada (a chamada "coisa julgada material") e permitindo que o contribuinte insatisfeito possa socorrer-se da via judicial (art. 5ํ, XXXV, da CF).

A possibilidade de recorribilidade na esfera administrativa ocorre similarmente a esfera judiciária, composta de órgãos julgadores através de seções julgamento, há a elevação graus recursais para a concreta efetividade da atuação da ampla defesa, através dos recursos.

O Decreto-Lei 70.235/72, adveio da força dos Atos Institucionais de nำ 5 e de nำ 12, que legitimou a edição do Decreto-Lei de n 822/69, que delegou ao Poder Executivo a competência para regulamentar o processo administrativo fiscal.

Na mesma seara, em 2011 foi editado o Decreto de no 7.574, que passou a regulamentar o processo de determinação e exigência de créditos tributários da União, de consulta acerca de aplicação da legislação tributária federal e demais processos de matérias administradas pela Secretaria da Receita Federal, o Decreto de $\mathrm{n} \cong 7.574$.

O PAF apresenta espécies, sendo elas divididas pela fase não contenciosa, que advém de ato praticado por autoridade fiscal com o objetivo de cobrar tributo não recolhido; e a fase contenciosa, que se inicia com a imputação ao lançamento do auto de infração, o qual o contribuinte não concorda com a cobrança do crédito e vai se defender.

O alvo dessa pesquisa é a fase litigiosa do processo administrativo tributário com ênfase no direito de defesa do contribuinte através dos princípios de contraditório e ampla defesa.

Os referidos princípios estão impostos na CRFB em seu artigo $5^{\circ}$ inciso LV: "aos litigantes, em processo judicial ou administrativo, e aos acusados em geral são assegurados o contraditório e ampla defesa, com os meios e recursos a ela inerentes". Como se percebe é assegurado aos contribuintes se defenderem na esfera 
administrativa, respaldados constitucionalmente e com os meios e recursos a eles inerentes.

Para que o processo administrativo fiscal se inicie, é necessário a instauração de seu processo, e este parte-se através da instauração da ação fiscal, que é onde ocorre

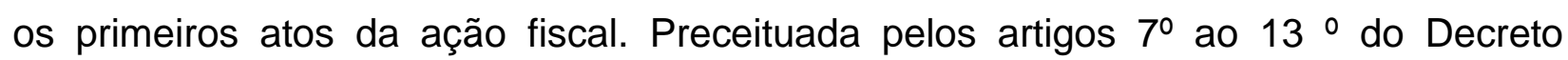
$70.235 / 72$, os quais dissertam sobre o procedimento em si, formalização e constituição do crédito tributário através do lançamento do auto de infração pela autoridade fiscal.

Nesta fase procedimental não há propriamente a oportunidade de defesa do contribuinte, pois neste momento estão sendo constituídos os atos adequando-os as normas tributárias, e é neste momento que está ocorrendo a fase não contenciosa.

Após o lançamento tributário, ocorrerá a possibilidade de exercício do contraditório e da ampla defesa para o contribuinte, em que o mesmo será notificado e em seguida será aberto o prazo para a impugnação ao lançamento tributário, podendo assim fazer jus a sua defesa e surtindo a partir daí a fase contenciosa do PAF. A princípio tratará-se só da fase não contenciosa no tópico seguinte.

\subsection{Processo Administrativo Tributário não contencioso}

A fase não contenciosa, também conhecida por processo administrativo voluntário, ou não litigioso é considerada assim devido ao art 14 do Decreto no 70.235/72, que por consequência lógica dispõe: a fase não litigiosa está em vigor até o momento da impugnação da exigência do crédito tributário pelo contribuinte. Quando ocorre a impugnação, é instaurado o litígio.

Pela não existência de litígio entre fisco e contribuinte nessa fase, a sua iniciação se dá pela consulta, que tem caráter preventivo e pela denúncia espontânea, citada pelo CTN, e que por sequência lógica deve ser apresentada pelo contribuinte antes de qualquer medida fiscalizatória pelo fisco.

A respeito da consulta, por ser prévia, ela ocorre quando o contribuinte de forma antecipada e formal apresenta ao Fisco uma solução referente a alguma situação jurídica de natureza tributária. 
Presente de forma íntegra, essa fase é disposta nos artigos 46 e 48 do Decreto 70.235/72:

Art. 46. Os interessados têm direito à vista do processo e a obter certidões ou cópias reprográficas dos dados e documentos que o integram, ressalvados os dados e documentos de terceiros protegidos por sigilo ou pelo direito à privacidade, à honra e à imagem.

Art. 48. A Administração tem o dever de explicitamente emitir decisão nos processos administrativos e sobre solicitações ou reclamações, em matéria de sua competência.

Em outras palavras a consulta pode ser definida como uma forma de resolução de dúvidas interpretativas as quais o contribuinte possua referentes a legislação tributária e aduaneira. Carneiro (2018, p. 65) ressalta no mesmo entendimento:

O termo inicial para adoção, pelo contribuinte beneficiado pela decisão, da solução adotada pelo órgão central, é a data de sua intimação. Esse procedimento visa, em síntese, dirimir perante a Fazenda dúvidas objetivas sobre a interpretação da legislação tributária e sua aplicação aos casos concretos, e tem como vantagem afastar a imputação das penalidades.

Assim a finalidade da consulta é esclarecer sobre a interpretação em si da norma tributária, e que ela deve ser fundamentalmente objetiva e relacionada a aplicação da lei ao caso concreto.

A respeito dos efeitos da consulta, o primeiro deles é a suspensão da instauração do procedimento fiscal em relação a matéria consultada, exclui os juros de mora se apresentada dentro do prazo legal, e quanto a solução da consulta, a mesma só terá validade se estiver vigente em norma legal que a interpreta e até a publicação de ato normativo que regule o fato consultado.

$\mathrm{Na}$ consulta, os processos administrativos serão solucionados em uma instancia única, não havendo aqui a possibilidade de recurso por parte do contribuinte ou de reconsideração de decisão proferida.

A denúncia espontânea é prevista no CTN em seu artigo 138 e é dividida em espontaneidade e o pagamento. O termo "denúncia" é caracterizado pelo ato do 
contribuinte comunicar por vontade própria a autoridade tributária acerca de ilícitos fiscais.

\section{PRINCÍPIOS FUNDAMENTAIS APLICÁVEIS NO MEIO DE DEFESA DO PROCESSO ADMINISTRATIVO TRIBUTÁRIO}

De princípios fundamentais a ampla defesa, discorre-se que a ampla defesa é garantia constitucional prevista na CF em seu artigo $5^{\circ}$ inciso LV, que se resume ao exercício do direito de apresentar alegações, propor, produzir e participar da produção de provas, ou outras providências que tenham efeito na defesa de interesses.

Sob pena de nulidade se não observado no processo administrativo, o princípio da ampla defesa apresenta-se como a oportunidade disposta ao sujeito passivo de opor-se a pretensão, e consequentemente que todas as suas alegações de caráter processual e material sejam conhecidas e apreciadas.

No Direito Tributário, por mandamento constitucional, obriga-se essa esfera a seguir as garantias constitucionais de direito a ampla defesa no processo, verificando e avaliando os pressupostos formais que perduram na relação do sujeito passivo com o Fisco, preservando sempre os limites de atuação da Administração Tributária e fiscalizando o cumprimento da mesma dos princípios constitucionais.

Ao falarmos de princípios fundamentais que se aplicam ao meio de defesa do contribuinte ou no Processo Administrativo Tributário, embasamos a execução da defesa do sujeito passivo através da sua conceituação principiológica na CF. De início será retratado sobre o conceito de princípios fundamentais, e em seguida os demais princípios que regem a ampla defesa.

\subsection{Princípios Fundamentais}

Primeiramente para adentrar aos princípios fundamentais que se aplicam ao meio de defesa no processo administrativo tributário, é de importância o entendimento prévio de Princípios Fundamentais. 
A Constituição Federal Brasileira em seu Título I, apresenta os "princípios fundamentais", e segundo ensinamento do doutrinador Pinho $(2018$, p.85) sobre o referido conceito:

Princípios fundamentais são as normas jurídicas informadoras do ordenamento constitucional brasileiro. Sobre essas diretrizes básicas foi elaborada a Constituição brasileira. Contêm os mais importantes valores que influenciaram a elaboração da Constituição da República Federativa do Brasil.

Logo, os princípios são repletos de normatividades que coordenam o ordenamento constitucional brasileiro de maneira vinculante, são espécies do gênero normas jurídicas, e também são referências para a escrita do texto constitucional. Por portarem um conteúdo mais idealístico, de estado ideal a ser alcançado, são repletos de moralidade, igualdade e dignidade da pessoa humana.

Os ensinamentos devem ser obedecidos a rigor e cumpridos, e que qualquer forma de relutância a norma infraconstitucional vem a violar os princípios institucionais, acentuando a ilegalidade desses atos.

De agora em diante serão relacionados os princípios constitucionais aplicáveis aos meios de defesa do contribuinte nos autos de infração do Fisco.

\subsection{Princípio do Contraditório}

O princípio do Contraditório encontra sua previsão expressa no art. 5, LV, da CF:"(...) LV - aos litigantes, em processo judicial ou administrativo, e aos acusados em geral são assegurados o contraditório e ampla defesa, com os meios e recursos a ela inerentes."

Sobre o conceito doutrinário do princípio do contraditório, Martins (2019, p. 1133) preceitua:

Contraditório, também chamado de audiência bilateral, é a soma da comunicação obrigatória com a reação possível. À parte, no processo judicial ou administrativo, tem o direito de ser comunicada de todos os atos processuais, em tempo hábil para que possa responder. 
O direito ao contraditório está presente em qualquer processo, e serve de proteção para aquele que quer recorrer, destarte no objeto de estudo deste artigo, isso ocorre quando o contribuinte não está de acordo com o lançamento tributário efetuado contra ele, e tem direito a contradizer a afirmação da pendência fiscal presente no auto de infração.

\subsection{Princípio da Ampla Defesa}

A ampla defesa é garantia constitucional imposta no artigo $5^{\circ}$ LV da Carta Magna, na qual é direito de todo cidadão apresentar suas alegações, produzir provas, sendo uma possibilidade de rebater em favor de si mesmo com argumentações, fatos.

O princípio do contraditório caminha junto com o da ampla defesa, tanto que ambos estão preceituados conjuntamente no art $5^{\circ}$ LV da Carta Magna, porém a doutrina sempre busca individualizar suas definições. Martins (2019, p. 1133) disserta sobre a ampla defesa: "ampla defesa consiste na possibilidade de utilização de todos os meios legítimos e legais para que possa se defender de alegações contrárias e de refutar decisões judiciais adversas."

Definida então a ampla defesa como a possibilidade para que o cidadão, através dos meios legais exerça o seu direito de defesa em processos incidentes sobre a sua pessoa.

Sobre a finalidade da incidência desses princípios no Processo Administrativo Fiscal, adentram como basilares estruturais para a construção dos recursos impugnação, recurso voluntário e recurso especial, os quais serão tratados mais adiante, disponibilizando dessa forma possibilidades de participação plena do contribuinte com o controle de abusos, controle de exacerbados benefícios fazendários, e oportunizando a estes a apresentação de fatos pertinentes, de provas que comprovem o contrário do alegado contra eles seja no auto de infração ou nas decisões das instâncias administrativas. 
Machado Segundo (2020, p. 37) preceitua nesse mesmo entendimento lecionando:

\begin{abstract}
Por ampla defesa entende-se que às partes em litígio devem ser assegurados todos os meios necessários à articulação de suas pretensões, à comprovação dos fatos sobre os quais estas se fundam e à reforma de decisões eventualmente equivocadas. (...) Um auto de infração, por exemplo, deve conter detalhadamente a descrição do fato imputado ao sujeito passivo, gerador do dever de pagar o tributo ou a multa então lançados, bem como dos dispositivos legais que a Administração entende aplicáveis. A falta desses requisitos, porque dificulta ou até inviabiliza a defesa do sujeito passivo, é causa para a nulidade da autuação. Não supre a exigência de fundamentação a mera referência lacunosa a uma "diferença de imposto apurada", ou outras frases igualmente vagas, que se enquadrariam a qualquer autuação, e por isso mesmo não fundamentam validamente nenhuma.
\end{abstract}

Fora a sua efetivação no processo administrativo tributário, o princípio da ampla defesa significa dizer que a Administração Pública deve ter fundamento e legalidade na execução de suas ações, nas execuções de cobrança de suas ações. Não basta por si só o agente público, por ser apenas dotado de competência tributária de cobrança em seu exercício não comprovar a origem lançamento, do tributo imputado ao contribuinte, ou mesmo a Administração na hora do julgamento dos recursos do sujeito passivo usar da parcialidade nas decisões proferidas, ou ocultar verdades. E que havendo descumprimento ou violação dos mesmos, os atos fazendários serão nulos por si só.

\title{
3.4 Princípio do Devido Processo Legal
}

O princípio do devido processo legal assegura que ninguém será privado da sua liberdade sem a realização e o cumprimento de todos os tramites processuais assegurados na norma legal. É um princípio amplo que abrange todos os campos do Direito. Martins (2019, p. 1132) diz:

Segundo o aspecto processual, devido processo legal consiste na somatória de direitos constitucionais aplicados ao processo: contraditório, ampla defesa, juiz natural, proibição de provas ilícitas, 
imparcialidade do juiz, igualdade entre as partes etc. (...) Por sua vez, segundo o aspecto material ou substantivo (substantive due process of law), também conhecido como princípio da razoabilidade, todo ato do poder público que não for razoável será inconstitucional.

Por ser um princípio substancial de vários outros princípios constitucionais como o contraditório, da ampla defesa, como também o do juiz natural, imparcialidade do juiz, igualdade entre as partes, ele pode ser classificado como gênero de todos os demais princípios, que serão as espécies.

Sendo que todos esses princípios abarcados tem o sentido da pura justiça na realização das decisões e/ous atos realizados pelo Poder Público, para que estes atos sejam legais, razoáveis e justos.

Consagrado na Constituição em seu artigo $5^{\circ}$, LIV "ninguém será privado da liberdade ou de seus bens sem o devido processo legal;", este princípio vem como um instrumento de ação do Poder Público na solução de controvérsias, porém sempre sendo garantido ao cidadão ser processado devidamente nos conformes legais.

Pinho (2018, p. 151) diz que o princípio do devido processo legal, também conhecido como "due process of law", é considerado um dos direitos individuais mais antigos da humanidade, e vem com o intuito assecuratório de proteção do cidadão para com a atuação arbitrária do poder do Estado.

No aspecto tributário esse princípio vem para designar o embasamento da defesa do contribuinte no processo administrativo, reafirmando que todo cidadão não poderá ser privado de seus bens até a tramitação processual final dos procedimentos do seu processo, com todo o direito de impugnação das decisões, conforme preceitua a Lei Maior.

\subsection{Princípio da Legalidade}

O princípio da Legalidade está disposto na CRFB em seu art. 37 caput que dispõe: "Art. 37. A administração pública direta e indireta de qualquer dos Poderes da União, dos Estados, do Distrito Federal e dos Municípios obedecerá aos princípios de 
legalidade, impessoalidade, moralidade, publicidade e eficiência", como também está presente no Sistema Tributário Nacional, no P.U do artigo 142, o qual faz afirmação de que o lançamento tributário é ato administrativo estritamente vinculado as normas legais.

A Administração Pública deverá atuar sempre e conforme a obediência a lei, seja ela em âmbito Federal, Estadual ou Municipal. Carneiro (2019, p. 784) correlaciona esse princípio constitucional no âmbito do Processo Administrativo Tributário dizendo:

A Administração Tributária, a pretexto de fiscalizar, arrecadar (obtenção de receita pública) e punir os infratores, não pode eximir-se de observar o princípio da legalidade. Significa dizer que a conduta dos fiscais pautase pela vinculação à lei, como ocorre no lançamento tributário.

A violação aos preceitos constitucionais de que qualquer ato, de qualquer ente federativo, praticado em desconformidade com as normas são caracterizados por atos de ilegalidade, e na seara do PAF vem com o propósito de coibir arbitrariedades e excessos dos administradores públicos.

\subsection{Princípio da Verdade Material}

Princípio da Verdade material, também conhecido como princípio da busca pela verdade real, é derivado do princípio da legalidade, e ele ordena que a autoridade Administrativa busque sempre aquilo que é verdade, ao invés de presumir com base em constatações baseadas em mera suposição. Sobre esse enfoque Machado Segundo (2020, p. 47) completa:

Quanto à presunção de "veracidade" dos atos administrativos, é evidente que ela não impede que a própria Administração procure confirmar se os fatos sobre os quais se fundamenta o ato impugnado realmente ocorreram, ainda que diante de defesa apresentada por contribuinte desacompanhada das "provas" de todas as suas afirmações. Basta que se aponte, na defesa, a necessidade de serem produzidas outras provas com as quais a citada "presunção", que não é absoluta, será afastada. 
E na mesma seara o CARF, Conselho de Contribuintes do Ministério da Fazenda, emitiu uma decisão:

\section{(...) ÔNUS DA PROVA.}

Cabe à autoridade lançadora provar a ocorrência do fato constitutivo do direito de lançar do fisco. Comprovado o direito de lançar cabe ao sujeito passivo alegar fatos impeditivos, modificativos ou extintivos e além de alegá-los, comprová-los efetivamente, nos termos do Código de Processo Civil, que estabelece as regras de distribuição do ônus da prova aplicáveis ao PAF, subsidiariamente.

Faz-se de inteira responsabilidade da Administração, através da autoridade fazendária, do Fisco buscar a comprovação em matéria do fato gerador que impulsionou o lançamento tributário, verificar a ocorrência de possíveis erros de servidores que tenham inserido informações errôneas, contraditórias, etc. Dessa forma indo em busca sempre da verdade material, e não se limitar as provas juntadas nas versões das partes durante processo.

\section{O CONTRADITÓRIO E A AMPLA DEFESA NO PROCESSO ADMINISTRATIVO TRIBUTÁRIO}

O contraditório e a ampla defesa, como princípios constitucionais norteadores do direito de defesa, são amplamente concretizados no Contencioso do Processo Administrativo Tributário, pois é nesse momento que se oportunizado ao contribuinte se defender tempestivamente das alegações e imputações a ele impostas, o primeiro como forma de apresentar alegações, propor e produzir provas e o segundo é inerente ao próprio processo.

Ao ser concedido o momento do sujeito passivo opor-se a pretensão, sendo possível que o mesmo alegue seus fatos e provas de caráter processual e material, se efetiva o princípio da ampla defesa no processo administrativo. 
A Constituição Federal é uma constituição democrata, e por isso deve seguir rigorosamente o que disciplina, democracia é participação e a efetivação da contribuição de todos, e no processo isso se consolida através da garantia do contraditório como forma de manifestação de exercício democrático de poder.

A fase contenciosa do PAF se instaura a partir da utilização do instrumento de defesa do contribuinte, pela impugnação da exigência do crédito tributário através do recurso de impugnação, pois ninguém poderá ser atingido por uma decisão administrativa sem se abra também a oportunidade de defende e será melhor retratada a seguir.

\subsection{Processo Administrativo Tributário Contencioso}

Processo Administrativo Tributário contencioso, também conhecido como fase contenciosa do PAF, regrada pelo art. 14 do Decreto $n^{-}$70.235/72, dispõe: seu início ocorre no momento em que o sujeito passivo da ação, apresenta à Administração o seu pedido de impugnação, referente a possível ilegalidade do ato administrativo que exigiu o pagamento da exigência fiscal.

Paulsen, Ávila e Sliwka (2018 p. 93) conceituam no mesmo entendimento a respeito da impugnação: Impugnação tempestiva inicia litígio administrativo e suspende a exigibilidade do crédito tributário. Havendo impugnação, dá-se início à fase litigiosa de procedimento administrativo.

Quando houver impugnação de forma intempestiva não há litigio, e consequentemente não será instaurada a fase litigiosa. Assegura-se também através da impugnação administrativa, a obediência aos princípios constitucionais do devido processo legal, contraditório e ampla defesa.

Conforme consolidado pelo Código Tributário Nacional, em seu art. 151:

Art. 151. Suspendem a exigibilidade do crédito tributário: (...) III - as reclamações e os recursos, nos termos das leis reguladoras do processo tributário administrativo. Logo, entende-se que haverá a suspensão da 
exigência do crédito tributário, quando o sujeito passivo da obrigação tributária entrar com seu recurso administrativo de impugnação.

A suspensão da exigibilidade do crédito tributário é expressamente prevista no CTN, normatizando a sua existência em hipótese de impugnação por parte do contribuinte através dos recursos administrativos, reclamações.

O CTN também se posiciona acerca do prazo e de que forma a impugnação deverá ser redigida nos seus artigos 15 e 16:

Art. 15. A impugnação, formalizada por escrito e instruída com os documentos em que se fundamentar, será apresentada ao órgão preparador no prazo de trinta dias, contados da data em que for feita a intimação da exigência.

Art. 16. A impugnação mencionará:

I - a autoridade julgadora a quem é dirigida;

II - a qualificação do impugnante;

III - os motivos de fato e de direito em que se fundamenta, os pontos de discordância e as razões e provas que possuir; (...)

A peça de impugnação, defesa ou reclamação deverá ser apresentada pós notificação de lançamento tributário no prazo de 30 dias, redigida de forma clara e objetiva, obedecendo a forma da lei com relação a seus aspectos materiais e formais, caso o contribuinte não concorde com aquela cobrança.

Primeiramente sobre a produção de provas, analisa-se o artigo 9ํ do Decreto 70.235/72, o qual consta que compete à autoridade fazendária que o lançamento tributário venha conforme cumprimento da lei, e comprovem explicitamente o litígio. Caso não havendo cumprimento deste quesito, o ônus de prova na impugnação é da Administração, e não do Administrado. Machado Segundo (2020, p. 145) leciona nesse sentido:

O ônus de provar os fatos constitutivos do direito da Fazenda, direito este exercido através do ato impugnado, é da administração tributária, e não do impugnante, o qual ver-se-ia muitas vezes obrigado a produzir 
uma impossível "prova negativa". Na verdade, o que ao impugnante cabe provar são os fatos modificativos, extintivos ou impeditivos do direito da Fazenda Pública. Assim, por exemplo, caso ofereça impugnação a um lançamento alegando já haver sido pago o tributo lançado, ou alegando a existência de imunidade ou isenção, o impugnante terá de provar a ocorrência de tais fatos.

Quando há um lançamento tributário indevido o contribuinte não é obrigado a demonstrar e provar na impugnação que os fatos descritos no auto de infração de fato não aconteceram.

No mesmo entendimento a Lei Subsidiária do PAF, de no 9.785/99 (Lei de Processo Administrativo Federal) preceitua em seu artigo 36, que há a necessidade de fundamentação do ato de lançamento, e que cabe a autoridade competente a demonstração em documentos comprobatórios da infração.

Ao ser instaurada a fase contenciosa, através do recurso de impugnação, seu julgamento se dará em primeira instância, e conforme dispositivo de lei serão assegurados as conseguintes formas de recorribilidade ao longo do PAF.

\subsection{Julgamento em Primeira Instância}

O julgamento em primeira instancia ocorre após a impugnação do lançamento tributário, através do recurso de Impugnação e caberá as Delegacias da Receita Federal de Julgamento e órgãos colegiados compostos por agentes fazendários, como assegura o artigo I, do Decreto Lei no 70.235/72, decisão essa que pode ser favorável ou desfavorável ao contribuinte.

Carneiro (2018, p. 88) preceitua:

Impugnado o lançamento, o processo é encaminhado para o julgamento em primeira instância, que se dá nas Delegacias de Julgamento (Regionais). A decisão dessas Delegacias pode ser pela procedência do lançamento e, consequentemente, do procedimento administrativo, ou seja, o reconhecimento de que o Fisco agiu com toda a correção que o princípio da legalidade impõe, ou pela improcedência do lançamento (improcedência do procedimento administrativo), quando então estará reconhecendo que a impugnação está correta, ou seja, que o Fisco 
errou no procedimento administrativo tributário culminante na notificação de lançamento.

Diferente do que ocorre nas esferas judiciais, em que há uma relação triangular, na esfera administrativa tributária o próprio ente, que está fiscalizando é também o órgão julgador do processo e devendo cumprir fielmente as normativas constitucionais.

Apesar de não haver um terceiro julgador da lide do conflito entre dois agentes, esses órgãos julgadores devem funcionar obedecendo de forma rígida o princípio da impessoalidade ao proferir suas decisões.

Carneiro (2018, p. 91). leciona sobre os graus das decisões:

Uma vez culminando em improcedência do crédito lançado, o julgamento de primeira instância, há o recurso de ofício; sendo procedente, caberá recurso voluntário ambos distribuídos para julgamento por uma das seções do CARF, e internamente redistribuídos a uma das câmaras, em razão da matéria.

Quando a impugnação for procedente, significa que o contribuinte tem razão, ou seja, aquele lançamento feito foi total ou parcialmente incorreto, e então o crédito tributário será suspenso, e a depender do valor encerra o processo na primeira instancia ou vai para a segunda instancia. A subida do grau recursal ocorre quando o contribuinte não concordou com a decisão da primeira instância, podendo entrar desta forma com um recurso voluntário para a segunda instância.

\subsection{Julgamento Em Segunda Instância}

$\mathrm{Na}$ hipótese de improcedência do recurso administrativo de impugnação, da decisão proferida pela DRJ, o contribuinte poderá submeter a reexame em instancia superior conforme assegura o art.33 e o art. 25 Inciso II do Decreto Lei 70.235/72 através do "Recurso Voluntário", o qual deverá ser interposto tempestivamente em 30 dias, contados da data da ciência da decisão de primeira instância. 
O recurso de ofício, presente no art.34, serve para decisões desfavoráveis ao fisco, em que foi dado provimento ao recurso de impugnação e improcedência do crédito tributário lançado. Ambos os recursos serão julgados pelo CARF, Conselho Administrativo de Recursos Fiscais, órgão integrante do Ministério da Fazenda.

O Conselho Administrativo de Recursos Fiscais (CARF) é competente para o julgamento de recursos de ofício e voluntário de decisão de primeira instancia, conforme dito anteriormente.

Estruturado por Seções e pela Câmara Superior de Recursos Fiscais, em que a primeira é especializa por matéria e constituída por Câmara, e poderá ser dividida em Turmas; enquanto que a segunda será constituída por Turmas, e composta por Presidentes e Vice-Presidentes das câmaras, em que esses são formadas pelo Presidente do Conselho Administrativo de Recursos Fiscais, Vice-Presidente, Presidentes e Vice-Presidentes das câmaras.

O recurso Especial é um recurso submetido para a Câmara Superior de Recursos Fiscais (CSRF), não mais para o CARF, como ocorre com o voluntário e o ofício, mesmo sendo ele integrando a segunda instância. Integração essa advinda da alteração promovida pela Lei oㅜ 11.941/11.

Poderá será impetrado o recurso especial tanto pelo Fisco quanto pelo contribuinte, contra decisão de segunda instancia, dentro do prazo de 15 dias da ciência do acórdão ao interessado, de decisão que der a lei tributária interpretação incompatível com a que tenha dado outra câmara, turma de câmara turma especial ou a própria Câmara Superior de Recursos Fiscais, ou de decisão que der ou negar provimento ao recurso de ofício.

Caracterizada por decisão administrativa irreformável segunda preceitua o CTN, a decisão que promover o CSRF será tratada como uma coisa julgada na esfera administrativa. E a partir desse ponto, acorda-se a possibilidade para o contribuinte 0 ingresso da propositura de embargos declaração contra essa decisão, segundo entendimento firmado pela Portaria n. 256/2009 do Ministério da Fazenda, Regimento Interno do CARF. 
Há que se observar, que os meios de defesa no processo administrativo são respaldados na nossa base constitucional principiológica, conforme já citado no decorrer deste artigo.

\section{CONSIDERAÇÕES FINAIS}

O processo administrativo fiscal (PAF) ou processo administrativo tributário é comportado de diversos pontos, dentre eles abordados aqui principalmente foram sobre as suas fases, a litigiosa e a não litigiosa. A primeira como o próprio nome assegura, não é conflituosa, não apresenta sua iniciação através da discordância de fatos, enquanto que a segunda sim surge através da resistência do sujeito passivo quanto à imposição fiscal.

A Constituição Federativa do Brasil de 1988, o Código Tributário e o Decreto 70.235/72 dão o suporte assecuratório ao contribuinte no processo administrativo fiscal na resolução de conflitos, sendo primordial a ampla defesa e o contraditório e impedidas qualquer limitação aos recursos administrativos utilizados pelo sujeito passivo na relação tributária.

No decorrer deste artigo demonstrou- se os órgãos julgadores de cada instância administrativa recursal, consecutivamente na ordem recursal do mais baixo ao superior: as DRJ pelo recurso de impugnação, o CARF pelo recurso voluntário e de ofício e o CSRF pelo recurso especial, e principalmente que o contribuinte pode e deve se defender contra autos de infração ou decisões infundadas, contra atos fazendários arbitrários ou impessoais, dentre outros não concordes.

Os princípios fundamentais da Constituição norteiam e coordenam a ampla defesa do contribuinte, e impõem a devida obediência na aplicação processual tributária com relação a oportunidade do contraditório, e do cumprimento legal normativo que a Administração Pública deve seguir.

Em síntese este trabalho trouxe como pontos principais a importância do cumprimento das fases procedimentais de arguição de defesa do sujeito passivo no processo administrativo fiscal, com observância das garantias fundamentais. 
Por fim este artigo teve a intenção de explanar sobre as possibilidades de recorribilidade ao longo do processo administrativo tributário, quando recorrer, qual órgão julgará em cada instância seus recursos e principalmente deixar claro sobre o direito de defesa do contribuinte, pertencentes estes de forma imperativa nos mandamentos principiológicos fundamentais para que não fiquem à mercê do Poder Público e o resultado do presente artigo é uma simplificação, explanação e popularização do Processo Administrativo Fiscal.

\title{
REFERÊNCIAS
}

AMARAL, Igor Rosado do. A garantia constitucional do contraditório e da ampla defesa no processo administrativo tributário. Revista Jus Navigandi, ISSN 1518-4862, Teresina, ano 18, n. 3509, 8 fev. 2013. Disponível em: https://jus.com.br/artigos/23693/a-garantia-constitucional-do-contraditorio-e-da-ampladefesa-no-processo-administrativo-tributario Acesso em: 18 de ago. 2020.

\begin{abstract}
ARAUJO, Ana Lúcia Menezes. A ampla defesa no Processo AdministrativoTributário. Disponível em: https://repositorio.enap.gov.br/bitstream/1/3958/1/Ana\%20L\%C3\%BAcia\%20Menezes.2 084847298 Acesso em: 13 de ago. 2020.
\end{abstract}

BRASIL. Código Tributário Nacional. Lei n. 5.172, de 25 de outubro de 1966. Dispõe sobre o Sistema Tributário Nacional e institui normas gerais de direito tributário aplicáveis à União, Estados e Municípios. Disponível em: http://www.planalto.gov.br/ccivil 03/leis//5172compilado.htm Acesso em: 14 ago. 2020.

. Conselho Administrativo de Recursos Fiscais. Acórdão n. 3201-004.353. - -2 Câmara / 1 $1^{\underline{a}}$ Turma Ordinária. Publicado em 19/11/2018. Recorrente: Grupo Fartura De Hortifrut S.A. Interessado: Fazenda Nacional. Relator: Charles Mayer de Castro Souza. Brasília. 24 de out. 2018.2 Disponível em: https://carf.fazenda.gov.br/sincon/public/pages/ConsultarlnformacoesProcessuais/consu ItarInformacoesProcessuais.jsf Acesso em: 20 de agosto de 2020.

Constituição Federal. Brasília: Senado Federal, 1988. Disponível em: http://www.planalto.gov.br/ccivil 03/constituicao/constituicao.htm Acesso em: 10 set. 2020.

- Decreto n. 70.235 , de 06 de março de 1972. Dispõe sobre o processo administrativo fiscal, e dá outras providências. Disponível em: 
http://www.planalto.gov.br/ccivil 03/decreto/d70235compilado.htm. Acesso em: 10 set.2020. http://www.planalto.gov.br/ccivil 03/leis/19784.htm Acesso em: 06 ago. 2020.

CARNEIRO, Cláudio. Curso de direito tributário e financeiro. 8. Ed. São Paulo: Saraiva Educação, 2019.

. Processo tributário: administrativo e judicial. 6. ed. São Paulo: Saraiva Educação, 2019.

Educação, 2018.

. Processo tributário: administrativo e judicial. 5. Ed. São Paulo: Saraiva

CARVALHO FILHO, José dos Santos. Manual de Direito Administrativo. 33. Ed. São Paulo: Atlas, 2019.

. Processo administrativo federal 5. ed. rev., ampl. e atual. até 31.3.2013. São Paulo: Atlas, 2013.

CASSONE, Vittorio; ROSSI, Júlio César; CASSONE, Maria Eugênia Teixeira. Processo Tributário: Teoria e Prática. 15. ed. rev. atual. e ampl. São Paulo: Atlas, 2017.

HAIDAR, Raul. Defesa do contribuinte nos autos de infração do Fisco. Disponível em: https://www.conjur.com.br/2014-jul-21/justica-tributaria-defesa-contribuinte-autosinfracao. Acesso em: 15 de ago. 2020.

MACHADO SEGUNDO, Hugo de Brito. Processo tributário. 12. ed. São Paulo: Atlas, 2020.

MARINELA, Fernanda. Direito 12. ed. São Paulo: Saraiva Educação, 2018.

MATIAS, Rafael Fernandes. $O$ redirecionamento da execução fiscal e a supressão do Processo Administrativo Fiscal em relação ao responsável tributário. Disponível em: https://www.ibet.com.br/wp-content/uploads/2017/07/Rafael-FernandesMatias.pdf Acesso em: 14 de ago 2020.

NUNES JÚNIOR, Flávio Martins Alves. Curso de direito constitucional 3. ed. São Paulo: Saraiva Educação, 2019.

OLIVEIRA, Samuel de Paula Teles. Processo administrativo fiscal, os meios de defesa do contribuinte nos tributos de competência federal e questões 
https://repositorio.ufjf.br/jspui/bitstream/ufjf/3772/1/samueldepaulatelesdeoliveira.pdf. Acesso em: 14 de ago. 2020.

PAULSEN, Leandro; ÁVILA, René Bergmann; SLIWKA, Ingrid Schroder. Leis de processo tributário comentadas: processo administrativo fiscal, protesto extrajudicial de títulos e execução fiscal. 9. ed. São Paulo: Saraiva Educação, 2018.

PINHO, Rodrigo César Rebello. Direito constitucional: teoria geral da constituição e direitos fundamentais. 16. ed. - São Paulo: Saraiva Educação, 2018.

ROCHA, Sérgio André. Processo Administrativo Fiscal: Controle Administrativo do Lançamento Tributário. São Paulo: Almedina, 2018.

SABBAG, Eduardo. Manual de direito tributário. 8. Ed. São Paulo: Saraiva, 2016.

WOLFGANG, S. I. Curso de direito constitucional. Editora Saraiva, 2018. 